\title{
Geology of Nimba County, Liberia
}

G E O L O G I C A L S U R V E Y B U L L E T I N 15440

Prepared in cooperation with the Liberian Geological Survey under the auspices of the Government of Liberia and the Agency for International Development, U.S. Department of State

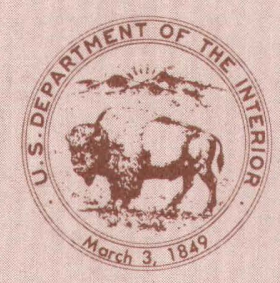





\section{Geology of Nimba County, Liberia}

By ERIC R. FORCE

G E O L O G I G A L S U R V E Y B U L L E T I N 15440

Prepared in cooperation with the Liberian Geological Survey under the auspices of the Government of Liberia and the Agency for International Development, U.S. Department of State

Precambrian rocks grouped in two initially separate tectonic terranes were juxtaposed, redeformed, intruded, metamorphosed, and then overthrust by rocks of a third, younger, Precambrian terrane

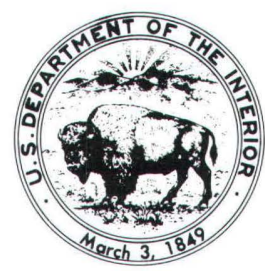




\title{
UNITED STATES DEPARTMENT OF THE INTERIOR
}

\author{
JAMES G. WATT, Secretary
}

GEOLOGICAL SURVEY

Dallas L, Peck, Director

\section{Library of Congress Cataloging in Publication Data}

Force, Eric R.

Geology of Nimba County, Liberia.

"Prepared in cooperation with the Liberian Geological Survey under the auspices of the Government of Liberia and the Agency for International Development, U.S. Department of State."

Bibliography: p.

Supt. of Docs. no: I 19.3:1540

1. Geology-Liberia-Nimba County. I. Liberian Geological Survey. II. United States. Agency for International Development. III. Title. IV. Series.
QE75.B9 no. 1540
$557.3 \mathrm{~s} \quad\left[556.66^{\prime} 2\right]$
$82-600081$
[QE339.L5]
AACR2

For sale by the Distribution Branch, U.S. Geological Survey, 604 South Pickett Street, Alexandria, VA 22304 


\section{CONTENTS}

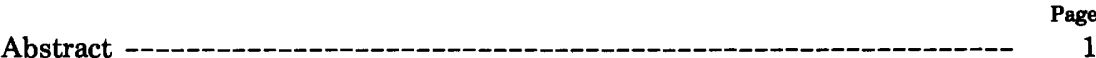

Introduction --_-_-_-_-_-_-_-_ 1

Purpose --_- 1

Character of Nimba County -_- 1

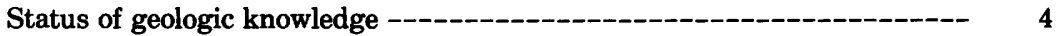

Methods used in this project --_ 5

Precambrian rocks -

Gneissic rocks --_-_- 6

Metasupracrustal rocks --_-_-_-_- 8

Metamorphosed mafic igneous rocks -_-_-_-_-_-_-_-_-_-_-_-_-_ 12

Igneous rocks -- 13

Phanerozoic rocks and deposits --_-_-_-_-_- 13

Structure --_-_ 14

Folds --_--_- 14

Faults --_-_- 16

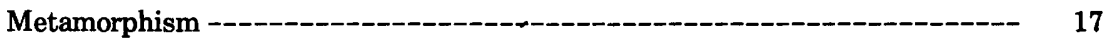

Granulite facies --_-_- 17

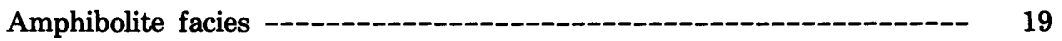

Dynamic metamorphism --_-_-_-_-_-_-_-_-_-_-_-_-_-_-_-_ 20

Precambrian stratigraphy and geologic history --_-_-_-_-_-_-_-_-_---- 20

Older units and events of the Gbedin-Kahnple area --_-_-_-_-_-_--_ 20

Older units and events of the Mt. Nimba area -

Younger units and events of the entire Sanokole-Mt. Nimba area --_-_--- 22

Eburnean(?) and younger events of eastern Nimba County --_-_-_-_--_ 23

Mineral resources -_-_-_-_ 23

Iron --_-_-_-_-_-_- 23

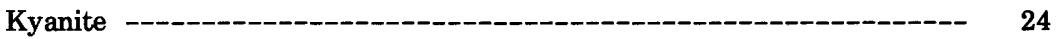

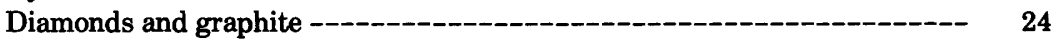

Kaolinite --_-_-_ 25

Tin --_-_-_-_-_-_- 25

References cited --_-_-_-_- 25

\section{ILLUSTRATIONS}

FIGURE 1. Index map of Nimba County -

2. Photograph of Nimba Range from the southwest --_-_-_-_-_- 3

3. Geologic sketch map of Nimba County --_- 8

4. Annotated photographic panorama to the south from Mt. Bele----- 10

5. Map showing former and present drainage pattern in northern Nimba County --_ 14 
6. Map showing distribution of folds of different ages in the Mt. NimbaSanokole area of Nimba County

7. Metamorphic-facies sketch map of Nimba County

8. Chart showing Precambrian stratigraphy and geologic history of

Nimba County

\section{TABLES}

TABLE 1. Radiometric ages of rocks from Nimba County

2. Chemical analyses of some Nimba County iron-formation rocks -----

3. Modal compositions of amphibolite and mesocratic pyroxeneplagioclase gneiss in lateral continuity --_-_-_-_- 


\title{
GEOLOGY OF NIMBA COUNTY, LIBERIA
}

\author{
BY ERIC R. FORCE
}

\section{ABSTRACT}

Precambrian rocks of Nimba County can be divided into three tectonic terranes: (1) a Nimba block of Nimba Supergroup supracrustal rocks containing isoclinal folds; (2) a Gbedin-Kahnple block, in which a folded granitic gneiss basement is unconformably overlain by iron-formation and leucocratic gneiss; and (3) a terrane of diorite, supracrustal rocks, and mafic rocks. The first two terranes were juxtaposed in an unknown manner and together were redeformed, metamorphosed (locally to granulite facies), and intruded by mafic rocks. The third terrane was later thrust over the first two. The histories of folding in the terranes were independent before juxtaposition but have been the same thereafter; four fold sets are recognized.

\section{INTRODUCTION}

\section{PURPOSE}

From 1963 to 1975, a joint project of the U.S. Geological Survey (USGS) and the Liberian Geological Survey, funded by the Agency for International Development, U.S. Department of State (PASA no.AFR(IC) 11-00), produced a geologic map of the entire country of Liberia as 10 quadrangle sheets at 1:250,000 scale. From 1970 to 1972 , the author was the principal investigator in Sanokole, Zwedru, and Gbanka quadrangles, which together make up most of Nimba County (fig. 1). This report attempts to synthesize the map information for the county.

\section{CHARACTER OF NIMBA COUNTY}

Nimba County is in northeastern Liberia and borders Guinea on the north and Ivory Coast on the east (fig. 1).

Geomorphology.-Altitudes range from about $150 \mathrm{~m}$, where the Cestos River flows out of the county, to more than 1,300 m at Mt. Nimba, the highest point in Liberia. Local relief is tens of meters between hills and streams on rolling terrain that characterizes most of 


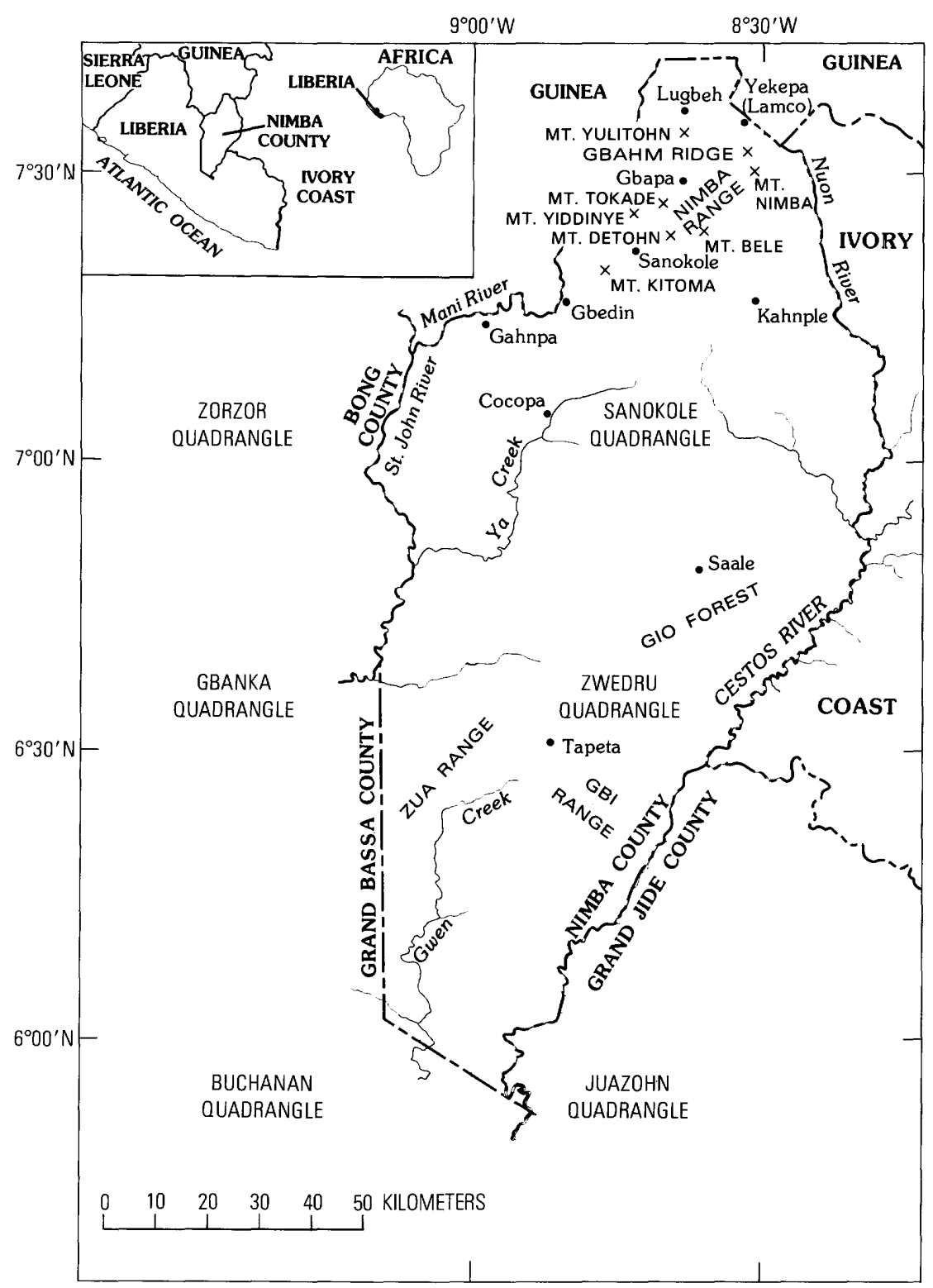

FIGURE 1.-Quadrangle boundaries and geographic localities of Nimba County.

the county. Long continuous ridges composed of metamorphosed supracrustal (sedimentary and volcanic) rocks stand as much as $800 \mathrm{~m}$ above the rolling terrain that is underlain by gneiss (fig. 2); these 
resistant ridges are a result of etching by chemical weathering of the landscape. Exposures of supracrustal rock on the ridges are much more common than are exposures of gneiss on the deeply weathered rolling terrain.

The rivers have quiet stretches, about a kilometer long, separated by rapids or falls, where the rivers commonly divide into numerous channels separated by rock exposures in streambeds. In the streambeds, exposures of gneiss are generally more complete than those of some supracrustal rocks; because the gneiss is more resistant to mechanical weathering (in streambeds) and the supracrustal rocks are more resistant to chemical weathering (on the rest of the land surface), one can follow a river through a mountain range of supracrustal rocks, where there are no rock exposures in the banks, and come out on gentle country that has excellent streambed exposures of gneiss.

Climate and vegetation. - Nimba County extends from about lat $6^{\circ}$ to $8^{\circ} \mathrm{N}$. The tropical climate has alternating wet and dry seasons. Toward the north, annual rainfall is as little as $200 \mathrm{~cm}$. Temperatures are moderate all year in the highest parts of the county. Rain forest dominates except for a few savannahs at higher altitudes, most of which have formed on canga (iron-formation-pebble conglomerate).

Population and language.-The county seat of government is at Sanokole. Of the 100 or more towns having populations of more than 200 , many are accessible only by trail. Much of the population is dispersed in small tribal villages that show few modern influences.

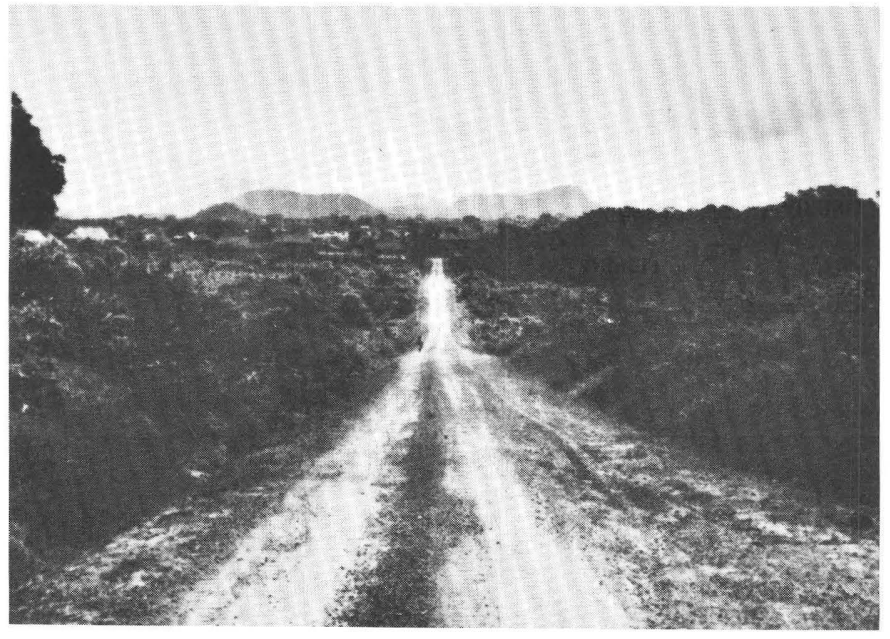

FiguRE 2.-Nimba Range viewed from the southwest, Mt. Bele (a synclinal keel(?)) on the right. The Nimba range is composed of metasedimentary and metavolcanic rocks of the Nimba Supergroup. Rolling terrain in the foreground is underlain by gneiss. Photograph by T. P. Thayer, 1949. 
Though English is spoken by many inhabitants, especially in the towns, the tribal languages Mano, Kpelle, Gio, and Gbi are most common.

Land use.-The largest industry of Nimba County, indeed of Liberia, is iron mining. The Liberian American-Swedish Mining Co. (LAMCO) operates mines at Mt. Nimba, Gbahm Ridge, and Mt. Tokade, all in the northern part of Nimba County (fig. 1).

Rubber plantations exist at several places in the county; the largest by far is Cocopa Plantation (fig. 1). Logging is also a large industry; hardwoods are logged selectively from magnificent stands of timber that remain in the Gio Forest and Gbi Range areas (fig. 1).

The most common occupation of Nimba County residents, however, is upland rice farming. Small plots of mature timber are cleared and burned, farmed for rice and other vegetables for a couple of years, and then allowed to revert to forest. At Gbedin, rice irrigation is being attempted under a government program.

Transportation system.-Most towns and villages are linked only by foot trails. The larger towns of Gahnpa, Sanokole, Yekepa, Tapeta, and Kahnple are linked by all-weather laterite-surface roads. Spur roads lead to other towns and logging operations. Many towns have airstrips suitable for light planes and courageous pilots. An iron-ore railroad leads from the LAMCO operations at Yekepa to the coast.

\section{STATUS OF GEOLOGIC KNOWLEDGE}

Despite efforts by the author and his colleagues and predecessors, the geology of Nimba County remains poorly known. Belts of supracrustal rocks probably remain to be discovered, as do important mineral deposits. Certainly, the origin of the gneiss that forms most of the county is poorly understood and needs further study.

Previous work.-Geologic work in Nimba County began in the 1940 's with investigations by T. P. Thayer and Arthur Sherman, but a great impetus to further work was provided by the discovery of the Nimba iron ores by Clarke in 1955 . Subsequent studies by LAMCO geologists were the first systematic geologic programs in the county. These studies resulted in reconnaissance geologic maps of an area that included most of Nimba County (Offerberg and Tremaine, 1961) and detailed geologic maps of the immediate area of the Nimba mines (Berge, 1968, 1971-1972). Berge $(1966,1974)$ also published on the petrology and origin of the iron ores.

Previous products of this project.-This report is based on information gathered during a cooperative program by the Liberian Geological Survey and the USGS from 1963 to 1972. The United Nations 
Development Program (UNDP) was also involved in mineral exploration during part of this period. Geologic maps of Nimba County were published as the following 1:250,000-scale quadrangles: Sanokole (Force and Berge, 1977), Zwedru (Force and Beikman, 1977), Zorzor (Seitz, 1977), Gbanka (Force and Dunbar, 1977), Buchanan (Tysdal, 1977a, 1978a), and Juazohn (Tysdal, 1977b, 1978b). Force and others (1971-1972) have described an aspect of the geology near Cocopa.

\section{METHODS USED IN THIS PROJECT}

Fieldwork was by the traverse method, as the vegetation and lack of outcrop made it difficult to follow contacts. Most of the traverses were along trails and consisted of observation of float boulders as well as of outcrops. Road and railroad traverses included observations of saprolite as well as of bedrock and float. Some of the most valuable traverses were along the St. John River, Ya Creek, Cestos River, and Gwen Creek. Travel here was by rubber boat during low water. Rock exposures along rivers were far better than elsewhere.

Data from magnetic and aeroradiometric surveys flown by Lockwood, Kessler, and Bartlett (Behrendt and Wotorson, 1974a-f; Wotorson and Behrendt, 1974a, b) were available before most of the fieldwork was done and served to guide the work. These maps were also helpful in locating contacts and outlining rock units. Both types of maps were useful in distinguishing gneiss from supracrustal sequences and amphibolite, which are typically more magnetic and less radioactive. Magnetic data locally provided information on the dip of contacts, and magnetic textures were used wherever possible to differentiate gneiss of slightly different character.

Base maps for fieldwork were prepared from uncontrolled air photomosaics by project personnel. The component aerial photographs are black and white infrared photographs of good quality at 1:40,000 scale. The geologic maps were published at 1:250,000 scale on shaded-relief maps derived from these bases (U.S. Geological Survey and Liberian Geological Survey, 1972a, b; 1973a, b).

Systematic photogeologic interpretation, mostly by the geologic map compilers, was an integral part of extending map patterns from information gathered on widely spaced traverses. Contacts, marker beds, fractures, structural attitudes, and dikes interpreted from photographs were plotted on 1:40,000-scale base maps. Many "fractures" interpreted from photographs proved of dubious importance. In many places, both geophysical information and photogeology indicated the existence of a feature; many traces on the ground surface could be located more precisely from the photographs than from geophysical 
maps. This was especially true for contacts of supracrustal sequences and for the location of dikes. We were concerned that photogeology in the "jungle" would be unrewarding, and indeed it took some familiarization, but in general, photogeology was a key to mapping in Liberia. In completely forested areas, the lack of confusing cultural boundaries and the excellence of "etching" produced by weathering compensated for the opacity of the trees.

Lithologic information and structural attitudes from previous surveys were incorporated into maps made in this project. The numerous data in Offerberg and Tremaine (1961) were particularly useful, as their rock identifications are consistent and their locational accuracy good; their traverses were therefore not duplicated. Their correlations and interpretations were not accepted, however, because their work was done before the existence of adequate air photographs or geophysical information. Data from Contri (1966) and Lemarchand (1966) along the Ivory Coast border were used in a similar manner.

\section{PRECAMBRIAN ROCKS}

Liberia is in Precambrian crystalline terrane; radiometric ages on rocks from Nimba County range from 2,230 to 2,950 million years (m.y.) (table 1). Four clans of Precambrian rocks are apparent. The most abundant is quartzofeldspathic gneiss. Another important clan is the clearly metasedimentary-metavolcanic sequences of schist, quartzite, and iron-formation, which form the mountain ranges. Mafic rocks that locally formed by metamorphism of sills are a third component. The last clan consists of relatively unmetamorphosed dioritic rocks (fig. 3).

\section{GNEISSIC ROCKS}

Leucocratic gneiss.-Leucocratic gneiss (gnl) is used here as a general term for quartzofeldspathic gneiss that occupies huge tracts of the county. The unit occupies an area of low relief, and outcrops are sparse except along rivers. The gneiss is fairly homogeneous except in strain features and porphyroblast growth. Offerberg and Tremaine (1961) attempted to map these features. The typical mineral assemblage is quartz, two feldspars, and biotite. Foliation defined by biotite orientation is typically strong, and textures range from porphyroblastic augen gneiss to equigranular medium-grained gneiss.

The leucocratic gneiss is believed to be partly metaigneous, for the following reasons: It is fairly homogeneous, the only readily apparent 
TABLE 1.-Radiometric ages of rocks from Nimba County

[From Hurley and others, 1971; Hedge and others, 1975]

\begin{tabular}{|c|c|c|c|}
\hline Age (m.y.) & Rock unit sampled & Material analyzed & Method \\
\hline 2,950 & $\begin{array}{l}\text { feldspathized Nimba } \\
\text { Supergroup }\end{array}$ & whole rock & $\mathrm{Rb}-\mathrm{Sr}$ \\
\hline $2,650 \quad------$ & $\begin{array}{l}\text { feldspathized Nimba } \\
\text { Supergroup }\end{array}$ & whole rock & $\mathrm{Rb}-\mathrm{Sr}$ \\
\hline $2,200^{1}-------$ & $\begin{array}{l}\text { mica phyllite of } \\
\text { Nimba Supergroup }\end{array}$ & whole rock & $\mathrm{Rb}-\mathrm{Sr}$ \\
\hline $2,230 \quad-------$ & $\begin{array}{l}\text { mesocratic pyroxene- } \\
\text { plagioclase gneiss }\end{array}$ & $\begin{array}{l}\text { hornblende } \\
\text { (retrograde) }\end{array}$ & $\mathrm{K}$-Ar \\
\hline
\end{tabular}

${ }^{1}$ Questioned by Hedge and others (1975).

inhomogenities being those of deformation fabric and those of amphibolite bodies that are probably metamorphosed dikes. Mineralogy is mostly simple and consistent with calc-alkalic original compositions. This evidence is admittedly weak, and more work is badly needed.

Berge (1971-1972) has shown that in some parts of the county, leucocratic gneiss can be traced into metasedimentary sequences and thus is itself metasedimentary, at least in part. Other such places will be discussed individually later in the report. However, much of the leucocratic gneiss probably is older, partly metaplutonic rock on which supracrustal rocks were deposited. If this is true, then the most important contacts in the area, the unconformities at the bases of metasupracrustal sequences, must commonly be within leucocratic gneiss sequences where they are almost impossible to find.

Granitic gneiss.-The term "granitic gneiss" (gng) is used here for a little foliated rock having coarse-grained granitoid texture and local anatectic features that occupies the Gbedin-Kahnple area in the northern part of the county. The mineral assemblage is also essentially quartz, two feldspars, and biotite; potash feldspar is more abundant than plagioclase. Amphibolite bodies are rare within this unit. Exposure of granitic gneiss is better than that of leucocratic gneiss, as the average relief is greater, and the unit locally forms exfoliation domes (fig. 4). Migmatite is present, apparently because of partial melting; the neosome of this migmatite locally intrudes adjacent leucocratic gneiss. For reasons discussed later, granitic gneiss appears to be the oldest rock in the county. It is almost certainly a metamorphosed igneous rock. 


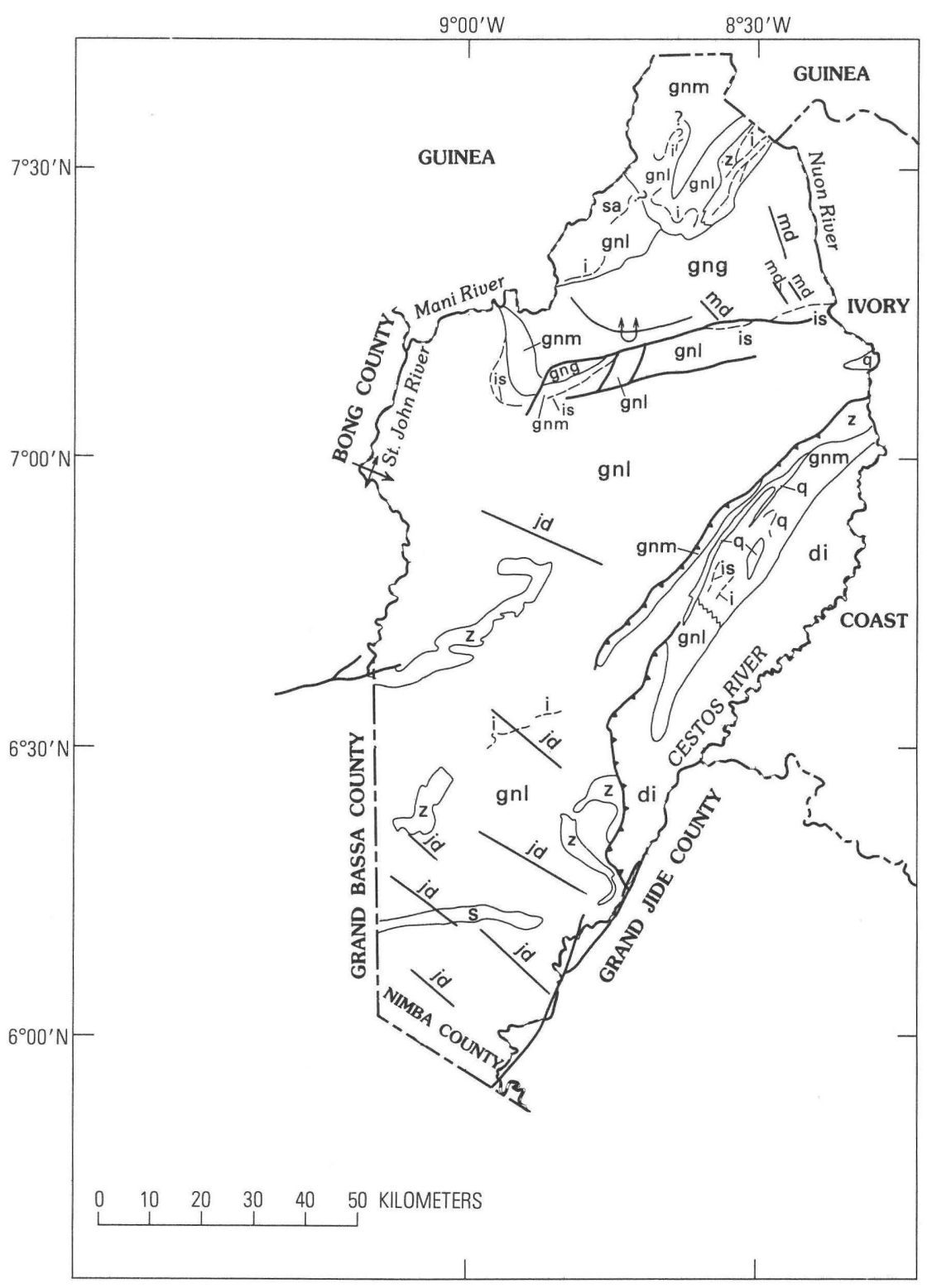

Figure 3.-Geologic sketch map of Nimba County. Units are described in text. METASUPRACRUSTAL ROCKS

"Metasupracrustal" here refers to sedimentary and volcanic rocks formed at the Earth's surface but later metamorphosed. 


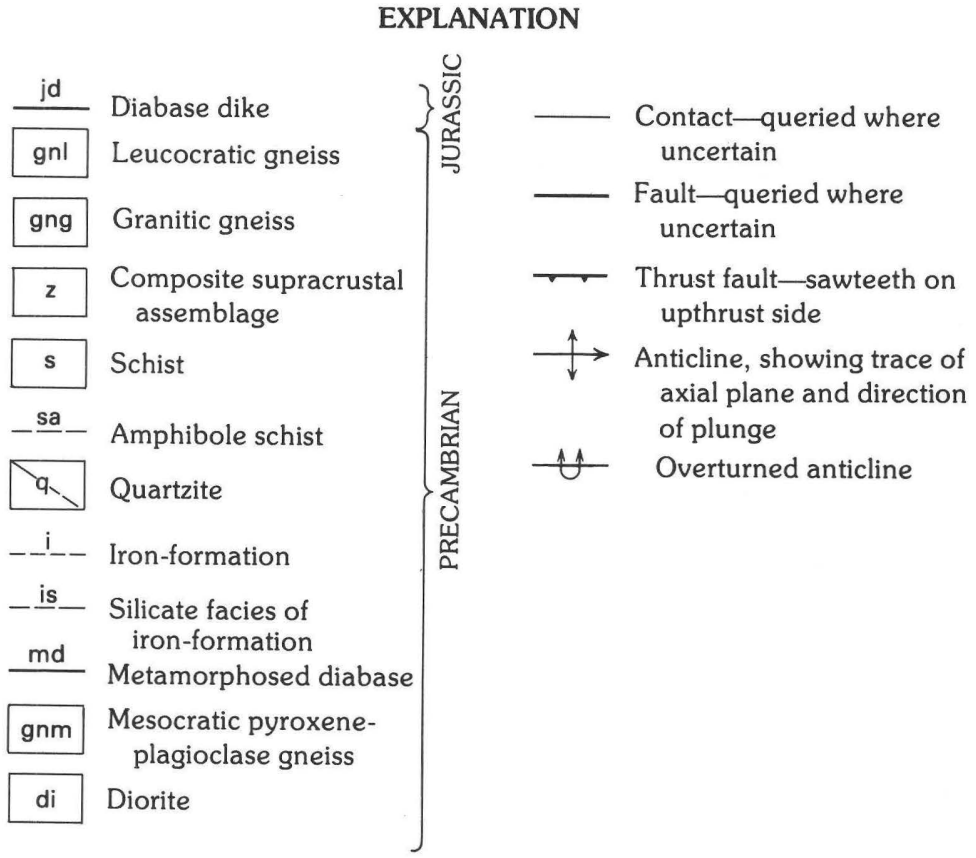

Assemblages of metasupracrustal rocks.-The most common assemblage of metasupracrustal rocks is a combination of mica or graphite schist, garnet, mica, magnetite-hematite, or kyanite quartzite, actinolite or hornblende-garnet-quartz amphibolite, and oxide or silicate facies of iron-formation. The assemblage is metasedimentary and metavolcanic and is believed to have been deposited on gneissic basement. A composite unit ( $\mathrm{z}$ ) has been used on the geologic maps and in figure 3 for the whole assemblage, where it cannot be further divided.

At Mt. Nimba, the Nimba Supergroup of Berge $(1968,1974)$ contains amphibole schist, quartz-mica schist, quartz-mica-graphite schist, and oxide-facies iron-formation in a well-defined stratigraphic sequence. In the northern part of Gbi Range, the assemblage is pure quartzite, magnetite quartzite, garnet-kyanite quartzite, mica schist, and oxide-facies iron-formation; the stratigraphic order is unknown. Most metasupracrustal sequences outside the Nimba area probably do not correlate with the Nimba Supergroup, so the term is not extended.

Schist.-The Nimba Supergroup contains quartz-mica schist and quartz-mica graphite schist (s). In addition, quartz-mica-garnet schist and minor amphibolitic schist are present along Gwen Creek in the southern part of the county. Natural exposures are few.

Quartzite.-Quartzite (q) is common and characteristic in the Gio Forest, where it holds up long narrow ridges, and in the Gbi Range. The unit includes relatively pure quartzite, magnetite- or hematitebearing quartzite, mica quartzite, garnet quartzite, and kyanite-garnet 


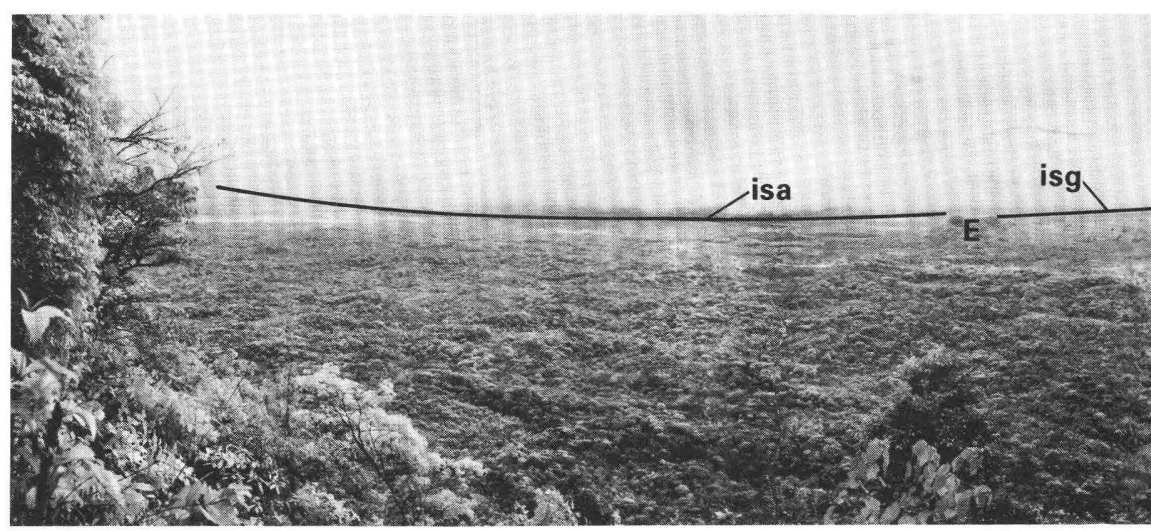

FIGURE 4.-Annotated panorama to the south from Mt. Bele. In the middle distance are exfoliation domes (E) of granitic gneiss. The black line traces the north contact of the silicate facies of iron-formation, which forms hills where metamorphism is of amphibolite facies (isa) but plains at granulite facies (isg). Mt. Kitoma (K) is composed of

quartzite. Quartzite with iron oxide and garnet is gradational into oxide and silicate facies of iron-formation, respectively.

Amphibolite.-The amphibolite of the metasupracrustal assemblage (sa) is distinct from amphibolites that are metamorphosed dikes and sills in gneissic terrane. The metasupracrustal amphibolite is either actinolite-cummingtonite rock, locally schistose, or hornblendeplagioclase-garnet-quartz rock, whereas the hypabyssal intrusive rocks are hornblende-plagioclase amphibolite or pyroxene-plagioclase gneiss. Metasupracrustal amphibolite is present in the Nimba Supergroup and on Mt. Yiddinye near Sanokole, as well as in other composite metasupracrustal units.

Iron-formation.-Nimba County is well endowed with iron-formation (i). The Nimba Supergroup contains the oxide-facies Nimba Itabirite (Berge, 1966, 1968, 1971-1972, 1974), which is mined at Mt. Nimba, Gbahm Ridge, and Mt. Tokade. Different depositional conditions produced both a simple oxide and a carbonate- and silicate-bearing oxide facies. Metamorphic grade ranges from greenschist facies to pyroxenegranulite facies, as indicated by the assemblages actinolite-chlorite and orthopyroxene-garnet.

Oxide-facies magnetic iron-formation at Mt. Kitoma is possibly also of economic importance.

A silicate-facies iron-formation (is) extends for more than $60 \mathrm{~km}$, from near Gahnpa past Kahnple (figs. 3 and 4), as four discrete segments. Variable metamorphic conditions have produced a banded iron 


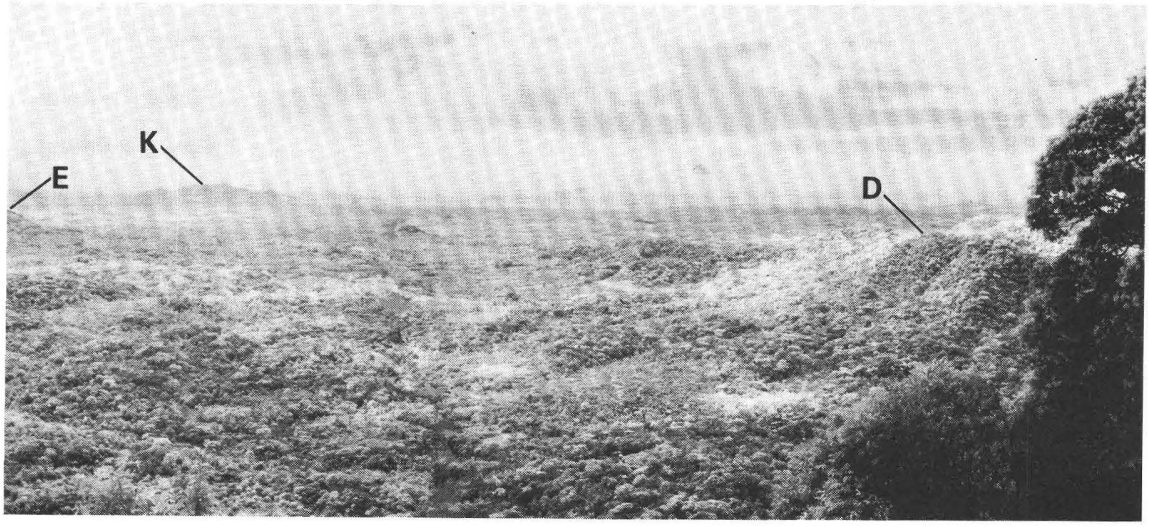

oxide-facies iron-formation. Mt. Detohn (D) is composed of Nimba Supergroup rocks. The stream that carried diamonds from Gbapa flowed through the valley between the location of the camera and Mt. Detohn. Photograph by T. P. Thayer, 1949.

orthopyroxene-garnet interval and a foliated grunerite interval (Force and others, 1971-1972).

A belt of metasupracrustal rocks along the St. John River extends into Nimba County and contains magnetic itabirite as a central spine of several ridges. The Zua Range contains a similar sequence that extends to near Tapeta. Another belt of oxide-facies iron-formation forms much of the Gbi Range and extends into Gio Forest, where orthopyroxene-bearing silicate facies of iron-formation is also present. Table 2 shows the few available chemical analyses of Nimba County iron-formations.

Gneisses of supracrustal origin.-In a few localities, leucocratic gneiss clearly is interbedded or gradational with rocks known to be of supracrustal origin and thus must be either supracrustal in origin or the result of later injection. The important contacts (probably unconformities) between presumably older plutonic gneiss and metasupracrustal sequences must then be within leucocratic gneiss units at these localities. Three such localities are known in Nimba County. They are (1) the Nimba area where Berge (1974) found that the Nimba Supergroup of metasedimentary and metavolcanic rocks passes laterally into gneiss as metamorphic grade increases, only itabirite and graphite schist being left to mark their stratigraphic positions in the metasedimentary sequence; (2) the Gahnpa-Kahnple belt of silicate-facies ironformation, where a narrow belt of iron-formation seems to have been deposited above an unconformity on granitic gneiss, and leucocratic gneiss to the south must then overlie it; and (3) exposures of schist and quartzite on Gwen Creek, which pass gradationally into gneiss. 
TABLE 2.-Chemical analyses of some Nimba County iron-formation rocks

[Values are in weight percent of oxides present, no entry indicates value not determined or less than 0.1. From

Berge, 1971-1972, 1974; Force and others, 1971-1972]

\begin{tabular}{|c|c|c|c|c|c|c|c|c|c|c|}
\hline \multirow[b]{2}{*}{ Oxides } & \multicolumn{10}{|l|}{ Sample } \\
\hline & No. & 1 & 2 & 3 & 4 & 5 & 6 & 7 & 8 & 9 \\
\hline $\mathrm{SiO}_{2}$ & --- & 40.4 & 39.7 & 40.2 & 40.4 & 39.8 & 1.5 & 1.5 & 49.2 & 48.6 \\
\hline $\mathrm{Al}_{2} \mathrm{O}_{3}$ & ---- & .4 & .1 & .3 & .9 & .3 & .5 & .8 & 3.7 & 6.4 \\
\hline $\mathrm{Fe}_{2} \mathrm{O}_{3}$ & ---- & 35.5 & 44.0 & 55.6 & 41.4 & 33.1 & 97.0 & 93.7 & 6.5 & 3.2 \\
\hline $\mathrm{FeO}-$ & -- & 18.1 & 12.9 & 1.1 & 13.3 & 17.4 & & & 35.0 & 34.0 \\
\hline $\mathrm{MgO}$ & --- & 1.8 & .6 & .2 & .1 & 1.8 & & & 3.3 & 4.1 \\
\hline $\mathrm{CaO}$ & - - - & 1.8 & .3 & .7 & 1.2 & 2.3 & & & .6 & .7 \\
\hline $\mathrm{Na}_{2} \mathrm{O}$ & ----- & .2 & & & & & & & & \\
\hline $\mathrm{K}_{2} \mathrm{O}$ & ----- & .2 & .1 & & .2 & & & & .1 & .1 \\
\hline $\mathrm{P}_{2} \mathrm{O}_{5}$ & ---- & .2 & .1 & .2 & .2 & .2 & & & .1 & .1 \\
\hline
\end{tabular}

${ }^{1}$ Average silicate-bearing itabirite, Mt. Tokade-Mt. Yulitohn.

${ }^{2}$ Average magnetic itabirite, Nimba.

${ }^{3}$ Average hematite itabirite, Nimba.

${ }^{4}$ Average silicate-bearing magnetic itabirite, Nimba.

${ }^{5}$ Average silicate-bearing itabirite, Gbahm Ridge.

${ }^{6}$ Average "blue" (hematite) ore.

${ }^{7}$ Average "brown" (goethite) ore.

${ }^{8}$ Orthopyroxene-garnet silicate facies, Cocopa area.

${ }^{9}$ Grunerite silicate facies, Kahnple area.

\section{METAMORPHOSED MAFIC IGNEOUS ROCKS}

Plagioclase-hornblende amphibolite and plagioclase-pyroxene gneiss of Nimba County are thought to represent metamorphosed mafic dikes and sills.

In the Kahnple area, some bodies are clearly dikes in granitic gneiss, as their tabular and crosscutting nature is apparent in aerial photographs, and their texture and mineralogy are locally little altered from a diabase precursor. These rocks are massive, have hornblende coronas around earlier pyroxene, and locally grade into foliated amphibolite.

On Cocopa Plantation, mesocratic pyroxene-plagioclase gneiss (gnm) probably originated as sills intruded into a fold hinge along an unconformity between granitic gneiss and iron-formation. Intrusion was probably synchronous with granulite-facies metamorphism, as domains that have original diabasic texture remain. East of Cocopa, the granulite-facies mesocratic gneiss can be traced into melanocratic amphibolite. Presumably, these rocks have the same composition and origin. The paradox of different color indices is explained by the metamorphic reaction hornblende $\rightarrow$ pyroxene + plagioclase, in which a dark mineral of the amphibolite reacts in part to produce a light mineral in the granulite. 
TABLE 3.-Modal compositions of amphibolite and mesocratic pyroxene-plagioclase gneiss in lateral continuity

[From Berge, 1971-1972, table 1]

\begin{tabular}{|c|c|c|}
\hline Mineral analyzed & $\begin{array}{l}\text { Average of } 8 \text { amphibolites near Gbapa } \\
\text { (percent) }\end{array}$ & $\begin{array}{l}\text { Average of } 12 \text { gneisses near Lugbeh } \\
\text { (percent) }\end{array}$ \\
\hline Hornblende ------- & 64 & 38 \\
\hline Hypersthene ------- & 0 & 10 \\
\hline Diopside -- & 0 & 10 \\
\hline Plagioclase -- -- ----- & $27^{1}$ & $40^{2}$ \\
\hline Other ------------- & 9 & 2 \\
\hline
\end{tabular}

1These were andesine.

${ }^{2}$ These were andesine-labradorite.

Similar pyroxene-plagioclase rocks occupy the hinge of the same fold at the northern end of the county and in the Gbapa area. Berge (1971-1972) found the same color-index differences between amphibolite and equivalent mesocratic pyroxene-plagioclase gneiss in that area (table 3).

Mesocratic pyroxene-plagioclase gneiss also occupies a large area in the Gio Forest; its origin there is not known. Locally, it is blastomylonitic and forms the basal part of thrust sheets.

\section{IGNEOUS ROCKS}

The only nonmetamorphosed Precambrian igneous rock mapped in the county is a large body of diorite and quartz diorite (di), most of which is in tectonic contact with other units but which presumably was intrusive into leucocratic gneiss (cf. Tysdal, 1978a, b). The body is massive to slightly foliated, porphyritic, and contains primary tabular red plagioclase, hornblende, and deuteric biotite and epidote. Toward the western margin, a gently east-dipping shear foliation becomes progressively stronger until the rock becomes a garnetiferous blastomylonite. The mylonitic rocks appear to structurally overlie ironformation and quartzite near Tapeta.

\section{PHANEROZOIC ROCKS AND DEPOSITS}

Diabase forms northwest-trending dikes, mostly in the southeastern part of the county. These dikes are Jurassic in age on the basis of evidence elsewhere in Liberia (Dalrymple and others, 1975). Exposures in Gwen Creek show that the dikes are unaltered and locally are more than $10 \mathrm{~m}$ thick. 
Canga (conglomerate containing iron-formation clasts and ferruginous cement) and laterite form mappable bodies underlying relict land surfaces on the flanks of Nimba Range. Fluvial deposits are widespread though difficult to map; they include deposits in modern valleys and deposits formed in former valleys now stranded on drainage divides. The distribution of diamond-bearing gravels derived from the Gbapa area reveals a former drainage pattern significantly different from the present one (fig. 5).

\section{STRUCTURE}

FOLDS

With the exception of folds mapped by Berge (1968), folds in Nimba County are not well known. However, there is evidence of relative fold ages in the Sanokole-Mt. Nimba area.

Four sets of folds have been recognized: Two older sets, probably formed in separate terranes, have been juxtaposed and deformed together by two younger fold sets, all mapped in the northern half of the county. The first set of older folds $\left(F_{1}\right.$ in fig. 6$)$ is confined to granitic

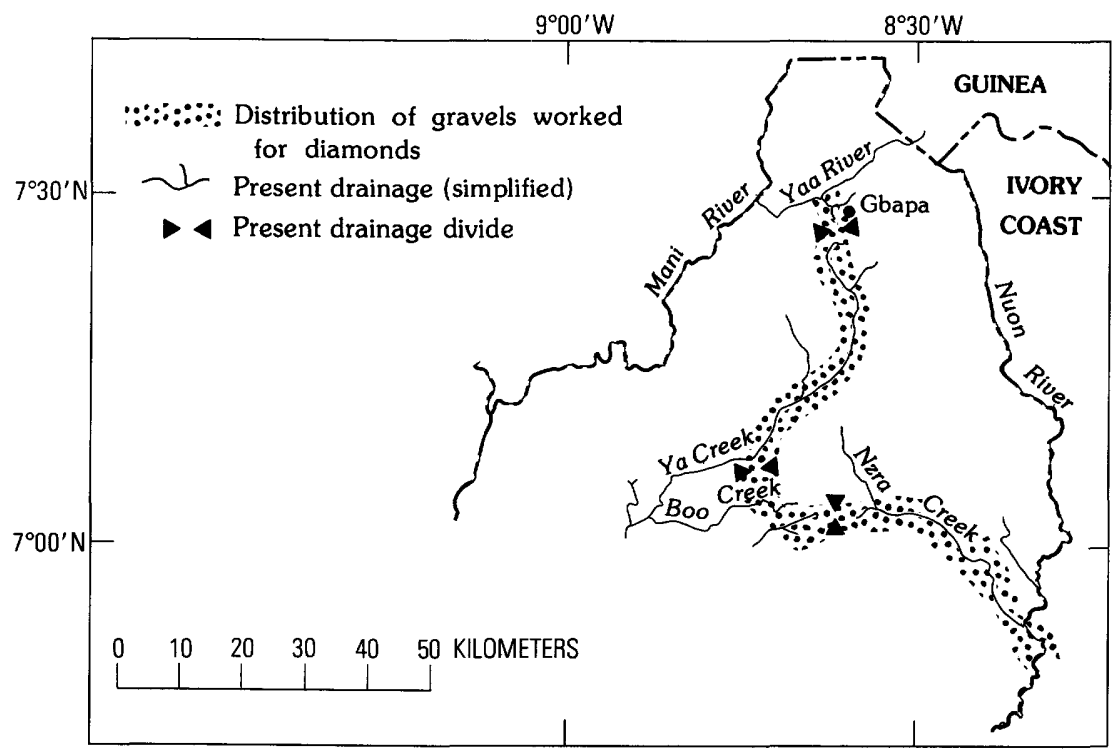

FIGURE 5.-Former and present stream drainage in northern Nimba County. The former drainage is interpreted from the distribution of pits in gravels worked for diamonds derived from the Gbapa area. 


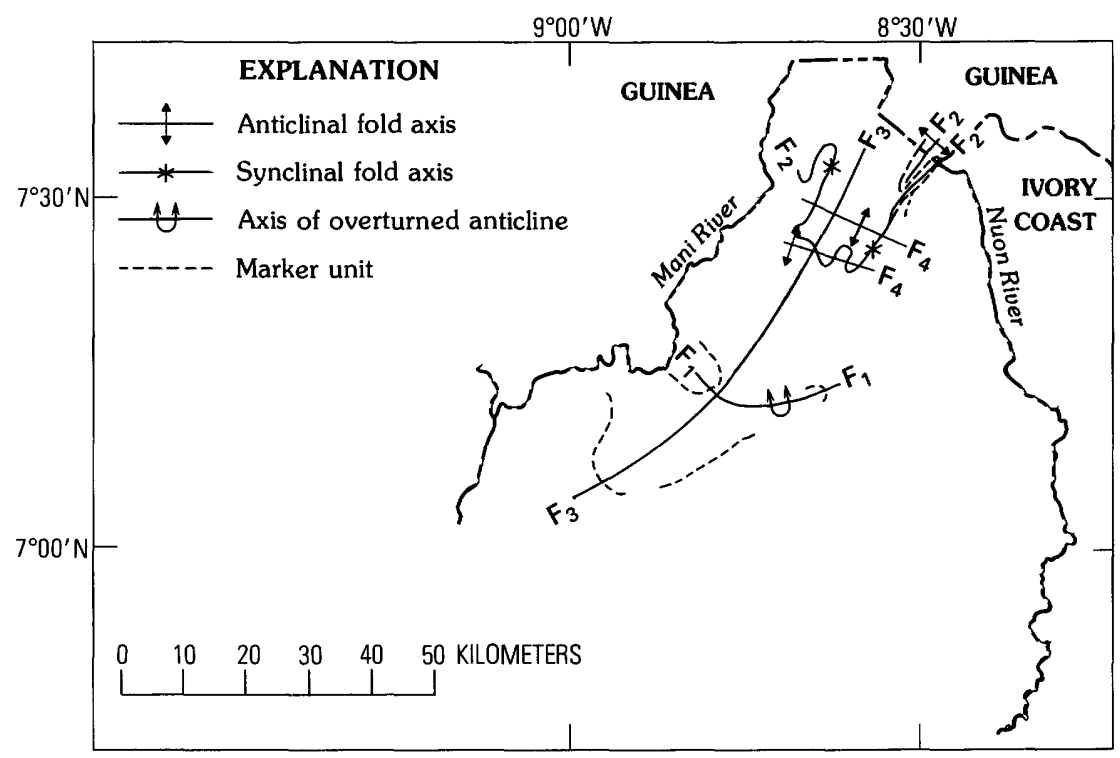

Figure 6.-Distribution of folds of different ages in the Mt. Nimba-Sanokole area. $F_{1}$ and $F_{2}$ are oldest, but they apparently formed separately, and their relative ages are unknown.

gneiss of the Gbedin-Kahnple area. This set consists of a single large eastward-closing refolded antiform that extends about $30 \mathrm{~km}$ southeast, then northeast, from Gbedin. Hinges can be traced in aerial photographs. The foliation of granitic gneiss has been folded. In map view, the fold appears isoclinal, though on the Gahnpa-Sanokole road, foliation dips gently away from the axial plane to the northeast and steeply on the southwest. This fold is truncated by a younger unconformity or fault, which separates it from rocks on Mt. Kitoma. The fold also formed prior to emplacement of diabase dikes, now metamorphosed, which are undeformed by the fold but restricted to granitic gneiss.

The second set of older folds ( $F_{2}$ in fig. 6 ) is restricted to the Nimba Supergroup and is most obvious in the Mt. Nimba-Gbahm Ridge area, where the folds were mapped by Berge (1968). The folds are nearly isoclinal. In the northern part of the range, they plunge southwest, but farther south in the range, plunge direction is reversed. If itabirite at Mt. Bele, Mt. Tokade, and Mt. Yulitohn is correlative with Nimba Itabirite and collectively younger than surrounding gneiss, it must represent the keels of tight synclines similar to folds in the Mt. Nimba area. The discontinuity of synclines results from interference by later folds. 
The third fold set ( $\mathrm{F}_{3}$ in fig. 6 ) refolds both the older sets. It consists of a single large open fold that closes at the southwest; its axial plane can be traced for more than $50 \mathrm{~km}$ southwestward from Nimba Range as it folds the older folds of Nimba Supergroup $\left(F_{2}\right)$, the older fold in granitic gneiss $\left(F_{1}\right)$, and iron-formation that overlies granitic gneiss. Mesocratic pyroxene-plagioclase gneiss was probably intruded as sills along the hinge of this fold in the Cocopa area and the Gbapa area.

The fourth set of folds $\left(\mathrm{F}_{4}\right.$ in fig. 6) consists of northwest-trending open upright folds that interfere with older folds in the Nimba Supergroup to produce the opposed plunges observed in Nimba Range and the dome-and-basin pattern of iron-formation to the west. These folds probably also produce the odd pattern of magnetic anomalies over the Nimba Range, in which large positive and negative anomalies alternate on the crest of the range. Similar folds were observed in the bed of the St. John River at the west end of the county, where foliation in leucocratic gneiss is folded into a slightly overturned open syncline. The trend of $\mathrm{F}_{4}$ folds parallels the characteristic trend of Pan-African (about 600 m.y.) deformation along the coast, and this fold set may be a distal effect of that deformation.

Other conspicuous folds in the county are in iron-formation at the south end of Zua Range, in quartzite of the Gio Forest, and in ironformation of Gbi Range. The last fold appears in aerial photographs to have been refolded. Correlation of these folds with the tentative fold chronology for the Mt. Nimba-Sanokole area has not been attempted.

\section{FAULTS}

The major faults in the county, from oldest to youngest in presumed age, are: a folded suturelike fault, a thrust fault, northeast-trending shear zones, and a possibly conjugate set of fractures. A folded suturelike fault in the northern part of the county (fig. 3) separates the terranes of $F_{1}$ and $F_{2}$ folding; this fault seems to be required if those terranes were unrelated during that early folding but were both folded by $F_{3}$. The position of the fault is uncertain except along the east flank of Nimba Range where it was mapped by Berge (1971-1972); its westerly extent is shown merely in plausible locations. The fault must be folded by $F_{3}$ and $F_{4}$ folds.

The most conspicuous faults in the county are imbricate thrusts in Gio Forest. They dip gently east and are marked by thick mylonitic zones, mostly blastomylonite, produced from rocks of the upper plate. The upper (eastern) thrusts have diorite on the upper plate, whereas lower (western) thrusts have mesocratic pyroxene-plagioclase gneiss 
on the upper plate. The eastern thrusts cut the boundaries of ironformation on the lower plate in Gbi Range. The northern end of the western segment is marked by discordant foliations rather than by mylonitic rocks. On the main road east from Tapeta, kaolinitic gouge crops out at the base of blastomylonitic diorite several hundred meters thick. The gouge probably represents continuation of faulting at a shallow crustal level.

Nearly vertical northeast-trending shear zones are conspicuous throughout much of Liberia. Nimba County has such zones along the Cestos River at its southeastern boundary (Cestos shear zone of Tysdal, 1977a) and along the Mani River at its northwestern boundary. A conspicuous shear zone along the St. John River (Force and Dunbar, 1977) fades just at the western boundary of the county. The zone along the Cestos River contains flinty ultramylonite. The zone along the St. John River is intruded by pegmatite and locally contains cassiterite, both of which may extend into Nimba County.

Immediately east of Cocopa Plantation, steep fractures divide the terrane into rhomb-shaped blocks. The fractures cut out the band of iron-formation at two places, providing good evidence of offset (probably vertical offset). Magnetic maps indicate that iron-formation is continuous at depth.

\section{METAMORPHISM}

The metamorphic assemblages are predominantly the result of a single event that postdates deposition of supracrustal sequences and the formation of two fold sets (fig. 6). This simplifies the study of metamorphism. Metamorphism is probably synchronous with $F_{3}$ folding and intrusion of sills as discussed later in the report.

A later dynamothermal metamorphism accompanied thrusting of diorite over rocks already metamorphosed.

\section{GRANULITE FACIES}

Metamorphic orthopyroxene is preserved mostly in mafic rocks and iron-formation in Nimba County. Biotite persists in the more extensive granitic gneiss and leucocratic gneiss. Much extrapolation between minor lithologies was therefore necessary to prepare figure 7. Locally, leucocratic gneiss contains pyroxene, as along the LAMCO railroad south of Gahnpa. 


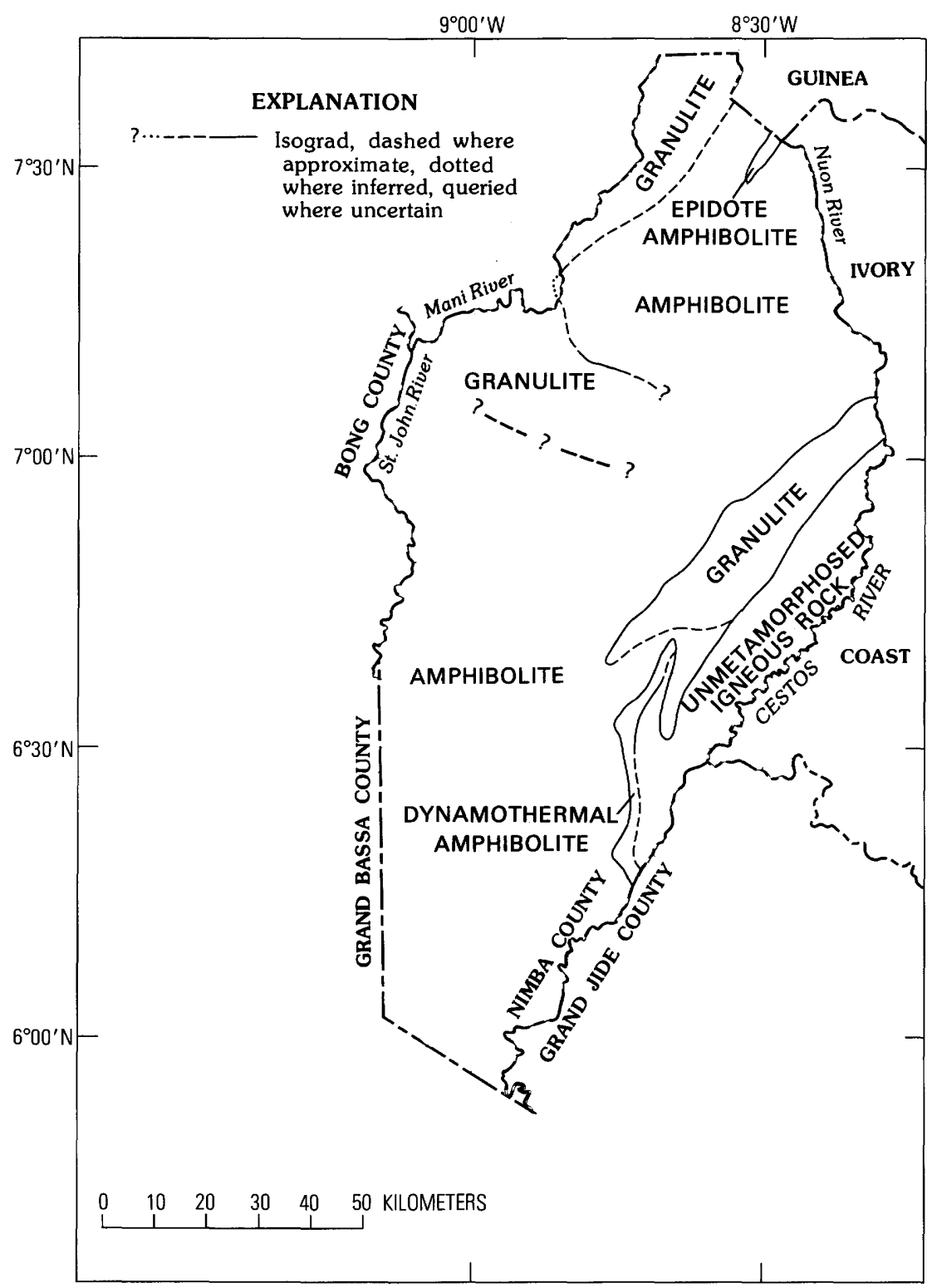

Figure 7.-Distribution of metamorphic facies in Nimba County.

Iron-formation of both oxide and silicate facies locally contains pyroxenes, including orthopyroxene. Force and others (1971-1972) reported that the dominant orthopyroxene in silicate facies of iron- 
formation in the Cocopa area is iron-rich, having the composition $\mathrm{En}_{14-16}$ (eulite). This pyroxene-bearing iron-formation traces eastward into iron-cummingtonite or grunerite-dominated assemblages that have the same chemical composition (table 2). Almandine-spessartine garnet is present in both facies. Berge (1971-1972, 1974) documented coarse pyroxene in oxide facies of iron-formation at Mt. Tokade, Mt. Yulitohn, and nearby locations. The silicate facies of iron-formation contains orthopyroxene in the Gio Forest area, most notably near Saale.

In the Cocopa area, orthopyroxene-bearing mesocratic gneiss is present only where adjacent iron-formation contains pyroxene (Force and others, 1971-1972). The pyroxene is clearly metamorphic at all but a few localities where original igneous textures are preserved. Berge (1971-1972) outlined an area of pyroxene-plagioclase mesocratic gneiss extending north and west from Gbapa; similar gneiss is widespread in the Gio Forest. The distribution of mesocratic pyroxene-plagioclase gneiss and of pyroxene-bearing iron-formation is thus the same. Force and others (1971-1972) suggested that the metamorphic significance of the iron orthopyroxene, eulite, is the same as that of ordinary hypersthene. Granulite-facies rocks of the Cocopa and Mt. Nimba areas are believed to be linked but are separated by granitic gneiss that does not contain pyroxene. The Gio Forest area is distinct and is separated from the Mt. Nimba and Cocopa areas by thrust faults.

To a considerable extent, the metamorphic facies of rocks having amphibolite composition can be traced on magnetic maps. Pyroxeneplagioclase mesocratic gneiss contains ilmenite rather than magnetite, whereas the amphibolite-facies equivalent, hornblende amphibolite, contains more magnetite. On magnetic maps, a granulite-facies terrane (except iron-formation) is an area of low magnetic relief, whereas equivalent amphibolite-facies rocks contain discrete anomalies over large bodies of amphibolite or high microrelief over a terrane of gneiss and small amphibolite bodies.

\section{AMPHIBOLITE FACIES}

Most rocks of the county show upper amphibolite-facies assemblages. Pelitic rocks are uncommon but, where present, as in Gbi Range, contain kyanite. Leucocratic gneiss is biotite bearing; mafic gneiss is hornblende bearing. Amphibolite-facies assemblages are also present in the granulite-facies area as a late overprint; pyroxenes in pyroxene-plagioclase mesocratic gneiss have hornblende rims. Hedge and others (1975) reported a 2,230-m.y. age for retrograde hornblende from such a rock (table 1). 
Berge (1971-1972) described a part of Nimba Range where phyllite contains lower amphibolite-facies assemblages. Actinolite schist in metasupracrustal sequences, as at Mt. Yiddinye and near the St. John River, may also represent lower amphibolite-facies conditions. If so, the coincidences of metamorphic breaks with contacts are evidence of unconformable or tectonic contacts between those metasupracrustal sequences and adjacent gneiss.

\section{DYNAMIC METAMORPHISM}

Blastomylonite of the Gio Forest area records deep-seated shearing, as diopside and garnet are present only in sheared diorite of the eastern thrusts, and orthopyroxene and garnet are present in sheared mesocratic gneiss of the western thrusts. This orthopyroxene is not relict, as grain size is larger than that observed in unsheared pyroxeneplagioclase mesocratic gneiss.

\section{PRECAMBRIAN STRATIGRAPHY AND GEOLOGIC HISTORY}

A stratigraphic succession of Precambrian rocks (fig. 8) of the Sankokole-Mt. Nimba area is implied by tentative chronologies of folding, faulting, and metamorphism already discussed. The stratigraphy of other parts of the county is less certain. Some supracrustal sequences, for example, in Zua Range, are probably complex synclines on gneissic basement, but this structure could not be demonstrated.

The two separate histories for the Gbedin-Kahnple area and the Mt. Nimba area together represent the oldest geologic events known in the county.

\section{OLDER UNITS AND EVENTS OF THE GBEDIN-KAHNPLE AREA}

Intrusion into an unknown host of the granitic rock (that subsequently became granitic gneiss) is the oldest event decipherable in the Gbedin-Kahnple area. The tight $\left(\mathrm{F}_{1}\right)$ antiform was formed prior to intrusion of diabase dikes (now metadiabase found only in granitic gneiss). The unit was then unroofed.

An unconformity on granitic gneiss is probably present around the entire unfaulted margin of the body but is most evident in the Gbedin area. There, leucocratic gneisses and iron-formation discordantly overlie foliated granitic gneiss and are unaffected by the $\left(F_{1}\right)$ fold. Stratigraphic contacts between leucocratic gneiss and iron-formation 


\section{Gbedin-Kahnple area}

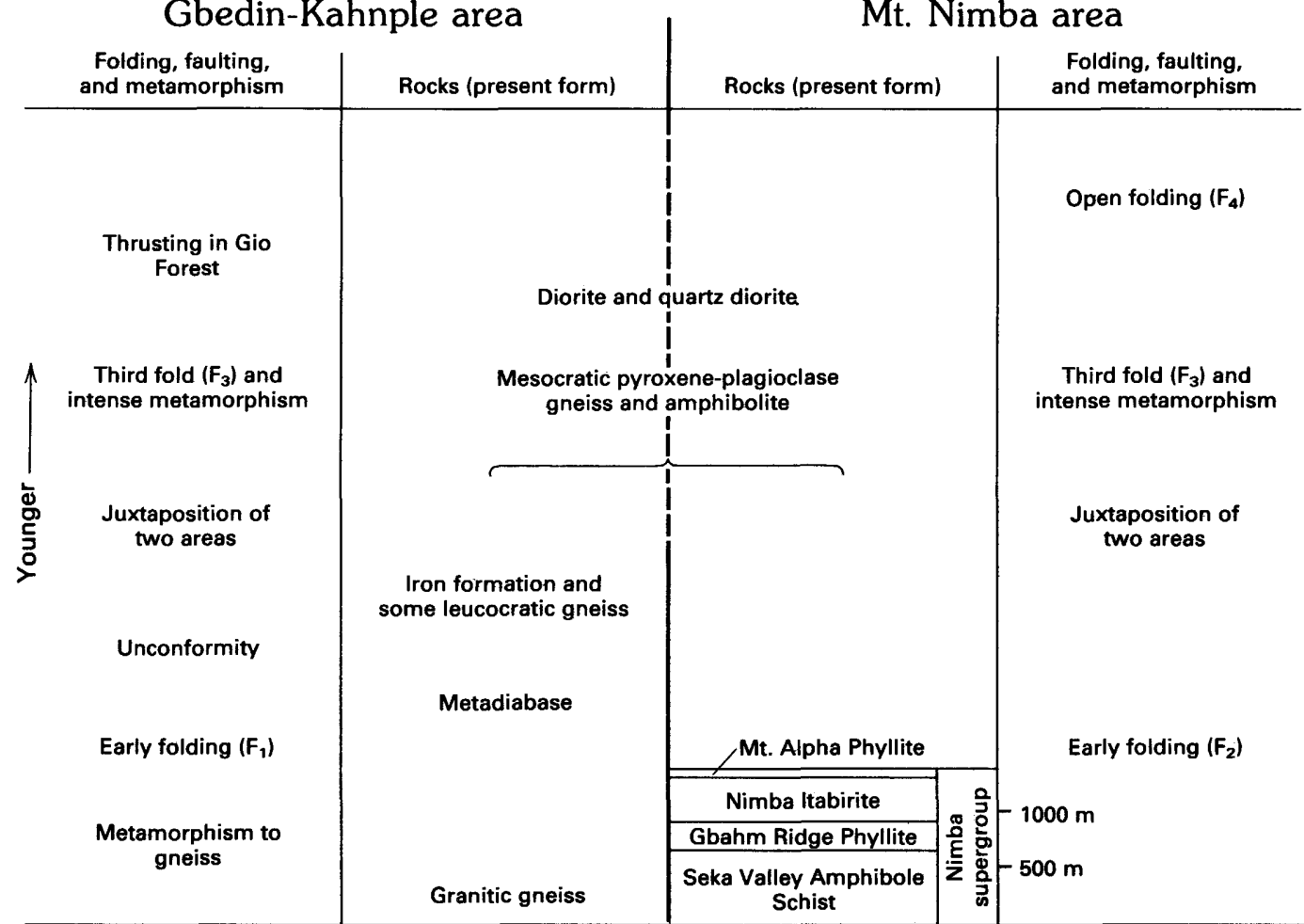

FIGURE 8.-Precambrian stratigraphy and geologic history of Nimba County. Thickness scale applies to Nimba Supergroup only. 
in the upper unit are parallel to the surface of the underlying unconformity. In the Kahnple area, the apparent lack of metadiabase dikes in iron silicate and leucocratic gneiss suggests that there, also, an unconformity separates older granitic gneiss from younger ironformation and leucocratic gneiss.

\section{OLDER UNITS AND EVENTS OF THE MT. NIMBA AREA}

The earliest recognized event in the Nimba area was deposition of the Nimba Supergroup (Berge, 1968, 1974), including associated rocks, which are now leucocratic gneisses containing marker graphite schist or iron-formation horizons traced into Nimba Supergroup (Berge, 1971-1972). Figure 8 shows Berge's stratigraphy of the Nimba Supergroup. These rocks were folded into tight to isoclinal folds $\left(F_{2}\right)$ described by Berge (1968).

An open fold closed to the southwest $\left(\mathrm{F}_{3}\right)$ is the oldest structure certainly shared by the Gbedin-Kahnple and Mt. Nimba areas. Presumably, rock sequences of the two areas, and older features already formed, were juxtaposed along a suturelike fault before the formation of this fold.

Metamorphism of the entire area is roughly synchronous with the formation of this open $\left(\mathrm{F}_{3}\right)$ fold, on the basis of the following evidence: Mesocratic pyroxene-plagioclase gneiss intruded into the hinge in both the Cocopa and Gbapa areas was almost completely metamorphosed after intrusion, along with other units. Local islands in this gneiss have relict igneous textures, suggesting intrusion into a metamorphic environment (that is, granulite facies) where its own mineralogy was stable. Thus, the $F_{3}$ fold, intrusion of sills into its hinge, and metamorphism all appear to be synchronous. Probably at the same time, the granitic gneiss became locally migmatitic. On the LAMCO railroad east of Gahnpa, the neosome of this migmatite intrudes and retrogrades pyroxene-plagioclase mesocratic gneiss along the contact.

The events discussed above are probably Liberian in age (about 2,700 m.y.) or older. Whole-rock rubidium-strontium metamorphic(?) ages of Nimba Supergroup (dates by Hurley and others, 1971, accepted by Hedge and others, 1975) are 2,650 and 2,950 m.y. The granitic gneiss unit probably is older yet. 
Hurley and others (1971) showed that radiometric ages of about 2,150 m.y. (Eburnean) are common in eastern Liberia. The only reliable radiometric age on rocks of Nimba County that can be assigned to the Eburnean is one for retrograde hornblende from a mesocratic pyroxene-plagioclase gneiss near Cocopa (2,230 m.y., Hedge and others, 1975). In the eastern part of the county, intrusion of dioritic rocks and later westward thrusting of these and other rocks seem likely to have been Eburnean events.

The diorite and quartz diorite are not metamorphosed except along thrust contacts, so they must postdate adjacent leucocratic gneiss. Unfortunately, intrusive contacts with leucocratic gneiss were not observed.

Thrusting in the Gio Forest area was clearly later than diorite on the upper plate of the eastern thrust or mesocratic pyroxene-plagioclase gneiss on the upper plate of the western thrust; both rocks are mylonitic along the thrusts. Thrusting is thus the next event in the chronology. Metamorphic conditions associated with thrusting locally reached granulite facies.

The last important event of the area is open upright folding $\left(F_{4}\right)$ that interferes with older folds to give doubly plunging synclines in the Mt. Nimba area. These folds may be Pan-African in age (about 600 m.y.).

\section{MINERAL RESOURCES}

Nimba County is an important producer of iron ore, and alluvial and bedrock mining for diamonds is conducted on a small scale. The county has kyanite, graphite, and kaolinite resources of unknown importance and cassiterite may also be present.

\section{IRON}

Iron ore is mined by LAMCO at Mt. Nimba, Gbahm Ridge, and Mt. Tokade; production capacity is about 12 million tons per year. The high-grade ore (63-68 percent iron (Fe)) is derived from itabirite (oxidefacies iron-formation) by some kind of metamorphic hydrothermal enrichment (hematitic "blue ore") and by. deep weathering (goethitic "brown ore," Berge, 1966). The ore was discovered in 1955, and reserves were estimated at 250 million tons (Berge, 1968); the 1978 estimate of the reserves of the western part of the area is $\mathbf{5 3 5}$ million tons. 
Much greater quantities of magnetite and hematite itabirite envelop the present ores and are themselves low-grade resources (see table 2 for composition).

Other iron-formation resources at Mt. Kitoma, Mt. Bele, and at the northernmost end of the county have been evaluated by LAMCO. Sequences containing iron-formation in Zua Range, the northern end of Gio Forest, and other places were examined by Offerberg and Tremaine (1961). The Saale part of Gio Forest contains some oxide-facies as well as silicate-facies iron-formation.

Oxide-facies iron-formation occupies much of the northern part of the Gbi Range, and judging from the similarity in aeromagnetic data and topographic expression of the two parts of the range, ironformation must be present in the southern part also. High-grade ore was not observed, but the traverses were few. Some of the itabirite consists of hematite rather than magnetite; all is coarse grained. In the northern part of the range, iron-formation is nearly horizontal over a considerable area.

\section{KYANITE}

In Gbi Range, abundant kyanite as much as $1 \mathrm{~cm}$ long was observed in kyanite-garnet schist (and soil) adjacent to iron-formation in several localities.

\section{DIAMONDS AND GRAPHITE}

Minor digging for alluvial diamonds is being conducted in the valleys of Yaa River and Ya, Boo, and Nzra Creeks (fig. 5). This digging formerly must have been more intensive, as these valleys are heavily scarred with pits. About 1965, digging for diamonds in graphite schist began near Gbapa.

The alluvial diamond diggings are presently in the drainages of four separate drainage basins, but they line up in such a way that they must have once been part of a single drainage that has been broken up by stream piracy. Diamond pits in gravel have been found in drainage divides separating parts of the former single drainage. The reconstructed drainage system had its head at Gbapa (see fig. 5).

Diamonds are being recovered from graphite schist at Gbapa. UNDP personnel recovered diamonds from unweathered unsheared graphite schist, though mining is concentrated along sheared and weathered zones, probably because the material is easier to disaggregate. The alluvial diamonds are derived from this graphite schist. 
The graphite schist is at most a few tens of meters thick and is concordant with adjacent muscovite gneiss. It is fine grained and contains perhaps 20 percent fine graphite. Rutile and tourmaline are the most abundant accessory minerals.

The origin of diamonds in this rock is a question that has implications beyond this deposit. I believe that the diamonds are neither of detrital nor regional metamorphic origin. The mineralogy and texture of the graphite schist rule out a detrital origin, as rutile, tourmaline, diamonds, and fine quartz do not make a plausible complete detrital assemblage. It is more likely that the diamonds are genetically related to the graphite, yet regional metamorphism of amphibolite facies is much too low for diamond formation. Local impact metamorphism may be responsible, but this hypothesis has not been investigated.

\section{KAOLINITE}

Kaolinitic fault gouge is exposed where the eastern thrust at the base of a diorite sheet crosses the main Tapeta-Zwedru road. This material is possibly thick and pure enough to warrant exploitation.

TIN

UNDP personnel have found cassiterite in greisenized pegmatite and in other rocks along the St. John shear zone $40 \mathrm{~km}$ west of the boundary of Nimba County. Alluvial cassiterite has also been found in this area. The shear zone, the pegmatite, and tin anomalies (Offerberg and Tremaine, 1961) extend roughly to the county boundary; thus, the presence of cassiterite in Nimba County is likely.

\section{REFERENGES GITED}

Behrendt, J. C., and Wotorson, C. S., 1974a, Aeromagnetic map of the Gbanka quadrangle, Liberia: U.S. Geological Survey Miscellaneous Investigations Series Map I-776-B, scale 1:250,000.

1974b, Aeromagnetic map of the Sanokole quadrangle, Liberia: U.S. Geological Survey Miscellaneous Investigations Series Map I-774-B, scale 1:250,000.

1974c, Aeromagnetic map of the Zorzor quadrangle, Liberia: U.S. Geological Survey Miscellaneous Investigations Series Map I-773-B, scale 1:250,000.

1974d, Total-count gamma radiation map of the Gbanka quadrangle, Liberia: U.S. Geological Survey Miscellaneous Investigations Series Map I-776-C, scale $1: 250,000$. 
1974e, Total-count gamma radiation map of the Sanokole quadrangle, Liberia: U.S. Geological Survey Miscellaneous Investigations Series Map I-774-C, scale 1:250,000.

1974f, Total-count gamma radiation map of the Zorzor quadrangle, Liberia: U.S. Geological Survey Miscellaneous Investigations Series Map I-773-C, scale $1: 250,000$.

Berge, J. W., 1966, Genetical aspects of the Nimba iron ores: Geological, Mining, and Metallurgical Society of Liberia Bulletin, v. 1, no. 1, p. 36-43.

1968, A proposed structural and stratigraphic interpretation of the NimbaGbahm Ridge area, Liberia: Geological, Mining, and Metallurgical Society of Liberia Bulletin, v. 3, p. 18-44.

1971-1972, Geology of the Nimba Concession area, Nimba County, Liberia (pt. 1): Geological, Mining, and Metallurgical Society of Liberia Bulletin, v. 5, p. 29-92.

1974, Geology, geochemistry, and origin of the Nimba Itabirite and associated rocks, Nimba County, Liberia: Economic Geology, v. 69, no. 1, p. 80-92.

Contri, J. P., 1966, Rapport de Fin de Levé Couperes Toulepleu 4c-4d Guiglo 3c-3d: Société pour le Développement Minier de la Cóte D'Ivoire Rapport 175 (1).

Dalrymple, G. B., Gromme, C. S., and White, R. W., 1975, Potassium-argon age and paleomagnetism of diabase dikes in Liberia; initiation of central Atlantic rifting: Geological Society of America Bulletin, v. 86, no. 3, p. 399-411.

Force, E. R., and Beikman, H. M., 1977, Geologic map of the Zwedru quadrangle, Liberia: U.S. Geological Survey Miscellaneous Investigations Series Map I-777-D, scale 1:250,000.

Force, E. R., and Berge, J. W., 1977, Geologic map of the Sanokole Quadrangle, Liberia: U.S. Geological Survey Miscellaneous Investigations Series Map I-774-D, scale 1:250,000.

Force, E. R., and Dunbar, J. D. N., 1977, Geologic map of the Gbanka quadrangle, Liberia: U.S. Geological Survey Miscellaneous Investigations Series Map I-776-D, scale 1:250,000.

Force, E. R., Srivastava, S. P., and Phillips, E., 1971-1972, Eulite rock and associated granulite facies gneisses from Nimba County, Liberia: Geological, Mining, and Metallurgical Society of Liberia Bulletin, v. 5, p. 93-111.

Hedge, C. E., Marvin, R. F., and Naeser, C. W., 1975, Age provinces in the basement rocks of Liberia: U.S. Geological Survey Journal of Research, v. 3, no. 4, p. 425-429.

Hurley, P. M., Leo, G. W., White, R. W., and Fairbairn, H. W., 1971, The Liberian age province (about 2,700 m.y.) and adjacent provinces in Liberia and Sierra Leone: Geological Society of America Bulletin, v. 82, no. 12, p. 3483-3490.

Lemarchand, R., 1966, Rapport de Fin de Levé Couperes Toulepleu 1d-2d-3b-4a-4b: Société pour le Développement Minier de la Cóte D'Ivoire Rapport 181.

Offerberg, J. O., and Tremaine, J. W., 1961, Report on LAMCO Joint Venture's geological investigations in Liberia between Nimba and Lower Buchanan along the Railroad Concession Area: Stockholm, W. Reklam/Caslon Press Boktr. AB, 74 p.

Seitz, J. F., 1977, Geologic map of the Zorzor quadrangle, Liberia: U.S. Geological Survey Miscellaneous Investigations Series Map I-773-D, scale 1:250,000.

Tysdal, R. G., 1977a, Geologic map of the Buchanan quadrangle, Liberia: U.S. Geological Survey Miscellaneous Investigations Series Map I-778-D, scale 1:250,000.

1977b, Geologic map of the Juazohn quadrangle, Liberia: U.S. Geological Survey

Miscellaneous Investigations Series Map I-779-D, scale 1:250,000.

1978a, Geology of the Buchanan quadrangle, Liberia: U.S. Geological Survey Bulletin 1449, 31 p.

$1978 \mathrm{~b}$, Geology of the Juazohn quadrangle, Liberia: U.S. Geological Survey Bulletin $1448,39 \mathrm{p}$. 
U.S. Geological Survey and Liberian Geological Survey, 1972a, Geographic map of the Gbanka quadrangle, Liberia: U.S. Geological Survey Miscellaneous Investigations Series Map I-776-A, scale 1:250,000.

$1972 b$, Geographic map of the Zorzor quadrangle, Liberia: U.S. Geological Survey Miscellaneous Investigations Series Map I-773-A, scale 1:250,000.

1973a, Geographic map of the Sanokole quadrangle, Liberia: U.S. Geological Survey Miscellaneous Investigations Series Map I-774-A, scale 1:250,000.

1973b, Geographic map of the Zwedru quadrangle, Liberia: U.S. Geological Survey Miscellaneous Investigations Series Map I-777-A, scale 1:250,000.

Wotorson, C. W., and Beherendt, J. C., 1974a, Aeromagnetic map of the Zwedru quadrangle, Liberia: U.S. Geological Survey Miscellaneous Investigations Series Map I-777-B, scale 1:250,000.

1974b, Total-count gamma radiation map of the Zwedru quadrangle, Liberia: U.S. Geological Survey Miscellaneous Investigations Series Map I-777-C, scale $1: 250,000$. 


